\title{
Internal Corrosion Analysis of Model 9975 Packaging Containing Pu or Pu02 During Shipping and Storage
}

\author{
by \\ P. Vormelker \\ Westinghouse Savannah River Company \\ Savannah River Site \\ Aiken, South Carolina 29808
}

This paper was prepared in connection with work done under the above contract number with the U.S. Department of Energy. By acceptance of this paper, the publisher and/or recipient acknowledges the U.S. Government's right to retain a nonexclusive, royalty-free license in and to any copyright covering this paper, along with the right to reproduce and to authorize others to reproduce all or part of the copyrighted paper. 


\section{DISCLAIMER}

This report was prepared as an account of work sponsored by an agency of the United States Government. Neither the United States Government nor any agency thereof, nor any of their employees, makes any warranty, express or implied, or assumes any legal liability or responsibility for the accuracy, completeness, or usefulness of any information, apparatus, product, or process disclosed, or represents that its use would not infringe privately owned rights. Reference herein to any specific commercial product, process, or service by trade name, trademark, manufacturer, or otherwise does not necessarily constitute or imply its endorsement, recommendation, or favoring by the United States Government or any agency thereof. The views and opinions of authors expressed herein do not necessarily state or reflect those of the United States Government or any agency thereof.

This report has been reproduced directly from the best available copy.

Available to DOE and DOE contractors from the Office of Scientific and Technical Information, P. O. Box 62, Oak Ridge, TN 37831; prices available from (423) 576-8401.

Available to the public from the National Technical Information Service, U. S. Department of Commerce, 5285. Port Royal Road, Springfield, VA 22161. 


\section{DISCLAIMER}

Portions of this document may be illegible in electronic image products. Images are produced from the best available original document. 


\title{
INTERNAL CORROSION ANALYSIS OF MODEL 9975 PACKAGING CONTAINING Pu OR PuO 2 DURING SHIPPING AND STORAGE (U)
}

\author{
Philip R. Vormelker \\ Savannah River Technology Center \\ Strategic Materials Technology Department \\ Materials Technology Section \\ Materials Consultation Group
}

Publication Date: January 1999

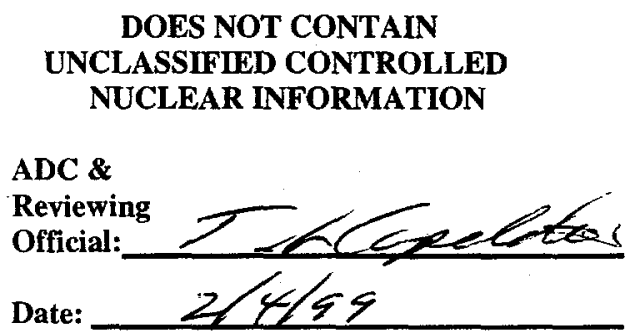

Westinghouse Savannah River Company

Savannah River Site

Aiken, SC 29808

This document was prepared in connection with work done under Contract No. DE-AC09-96SR18500

with the U.S. Department of Energy 
DOCUMENT: $\quad$ WSRC-TR-99-00030

TITLE:

INTERNAL CORROSION ANALYSIS OF MODEL 9975 PACKAGING CONTAINING Pu OR PuO ${ }_{2}$ DURING SHIPPING AND STORAGE (U)

TASK:

SRT-PTG-98-8007

\section{APPROVALS}

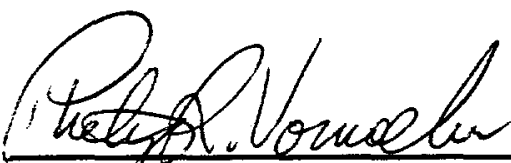

Date: 214199

Philip $k$. Vormelker, Author

Materials Consultation Group

MATERIALS TECHNOLOGY SECTION

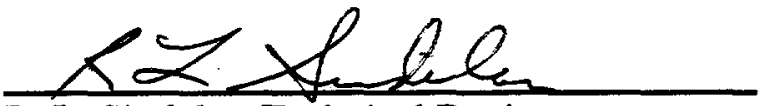

R. L. Sindelar, Technical Reviewer

Date: $2 / 4 / 99$

Materials Application and Corrosion Technology Group

MATERIALS TECHNOLOGY SECTION

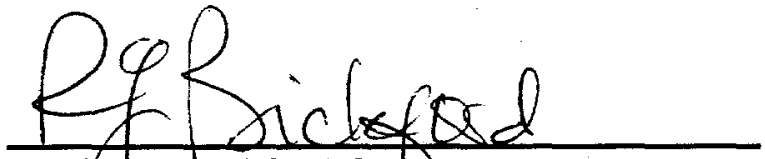

R. Linnea \&ickford, Mqnager Materals Consultation Group MATERIALS TECHNOLOGY SECTION
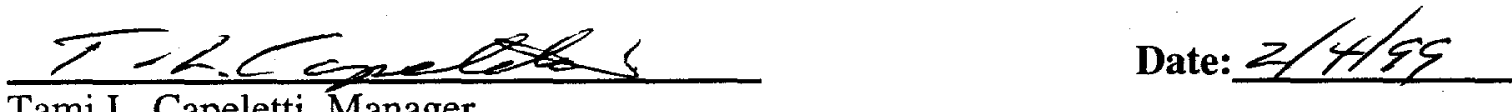

Tami L. Capeletti, Manager MATERIALS TECHNOLOGY SECTION

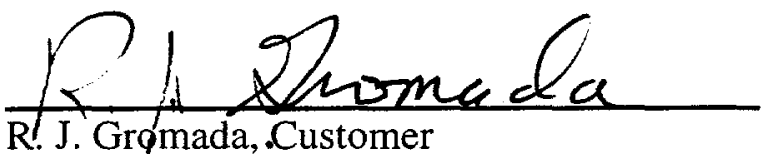

Date: 21499

Packaging and Transportation Group

ENGINEERED EQUIPMENT AND SYSTEMS DEPARTMENT 


\section{TABLE OF CONTENTS}

Page

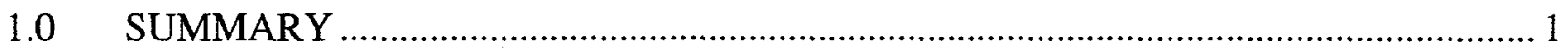

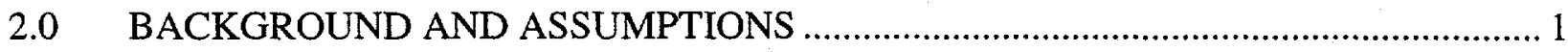

3.0 INTERNAL CORROSION ANALYSIS OF Pu SHIPMENT AND STORAGE......... 2

3.1 Corrosion of the Food Can ........................................................................... 2

3.2 Plutonium Reaction with Food Can Atmosphere........................................... 2

3.3 Discussion of Potential Degradation Mechanisms.................................. 3

4.0 INTERNAL CORROSION ANALYSIS OF PuO ${ }_{2}$ SHIPMENT AND STORAGE....... 4

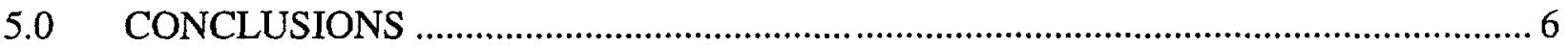

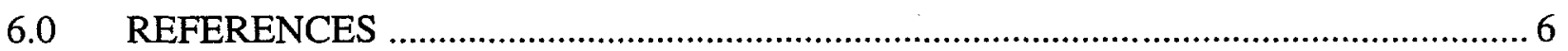




\section{LIST OF FIGURES}

Figure 1. Overall Schematic of the Model 9975 Packaging Assembly

Figure 2. Author's Conception of Model 9975 Shipping container showing Location of Vessels and Food Can with Dimensions.

Figure 3. Time Dependence of Mass Gain of Unalloyed Plutonium with Water Vapor at 15 Torr Pressure and Temperatures in the $50-300^{\circ} \mathrm{C}$ Range..

Figure 4. Arrhenius Data for the Reactions of Unalloyed Plutonium with Water Vapor and Water-saturated Air over the $25-400^{\circ} \mathrm{C}$ range..

Figure 5. Combined Arrhenius Data for the Reactions of Unalloyed Plutonium with Water and Oxygen in the High Temperature Regime and with Dry Air in the Low Temperature Regime.

\section{LIST OF TABLES}

Table 1. Plutonium Metal Feed Specifications for the Weapons Program .9

Table 2. Maximum and Average Impurity Levels found during Elemental Analysis of Specific Group A and B Metals.....

Table 3. Maximum and Average Impurity Levels found in $\mathrm{PuO}_{2}$ during Elemental Analysis of Selected Batches. 10

Table 4. Fe Corrosion vs. Available Water. 10

\section{LIST OF ABBREVIATIONS}

ASTM American Society for Testing and Materials

ASME American Society of Mechanical Engineers

PCV Primary Container Vessel

RFETS Rocky Flats Environmental Technology Site

SARP Safety Analysis Report for Packaging

SRS Savannah River Site

SRTC Savannah River Technology Center

SCV Secondary Container Vessel

SS $\quad$ Stainless Steel 


\subsection{SUMMARY}

The Materials Consultation Group of SRTC has completed an internal corrosion analysis of the Model 9975 packaging assembly containing either $\mathrm{Pu}$ or $\mathrm{PuO}_{2}$ for storage in $\mathrm{K}$ Reactor under ambient conditions for a period of 12 years. The 12-year storage period includes two years for shipping and up to ten years for storage. Based on review of existing literature and referenced conditions, corrosion of the 304L stainless steel (SS) Primary Containment Vessel (PCV) and the carbon steel food cans containing $\mathrm{Pu}$ or $\mathrm{PuO}_{2}$ is not significant to cause failure during the 12 year time period due to limited water content. The potential for embrittlement of the Primary Containment Vessel and the carbon steel can due to iron diffusion into plutonium (or plutonium diffusion into the steel) and gallium diffusion into the steel have been assessed. This phenomenon should not be significant during the storage period. The integrity of the stainless steel Primary Containment Vessel will not be impacted during shipping or storage. The Materials Consultation Group concludes that there are sufficient data to establish the technical basis for safe storage of $\mathrm{Pu}$ and $\mathrm{PuO} 2$ at the referenced conditions in the Model 9975 package in the $105-\mathrm{K}$ building for up to 10 years following the 2-year shipping period.

\subsection{BACKGROUND AND ASSUMPTIONS}

Pu-bearing materials (metal and oxides) currently stored at RFETS (Rocky Flats Environmental Technology Site) are to be shipped to SRS in Model 9975 packaging assemblies for interim storage prior to future disposition. The Model 9975 shipping package design ${ }^{1-2}$ includes an inner carbon steel food can (A), $0.025 \mathrm{~cm}$ thick, that will contain the RFETS material, Figures 1 and 2. Can A will then be placed into two, $0.005-\mathrm{cm}$ thick nylon bags (double bagging). The bagged can A will be placed inside a larger carbon steel food can (can B), also $0.025 \mathrm{~cm}$ thick. The carbon steel food cans are specified per MIL-C-10464 (1990). Two of the can B's will be stacked on one another and placed into the 304L stainless steel Primary Containment Vessel (PCV). The can B's will be supported on the bottom by an aluminum honeycomb structure to stabilize the cans within the primary container. The PCV is then placed inside a Secondary Container Vessel (SCV) that is also 304L SS. Aluminum honeycomb is also used to support the $\mathrm{PCV}$ within the SCV. Any interior corrosion occurring in this package will initiate from the inside of the initial food can A. No credit is taken for corrosion protection from any organic or tin coating on the food cans or the nylon bags. A discussion of external corrosion concerns can be found in Reference 3.

Multiple units of the Model 9975 packaging assembly will contain a maximum of either $4.5 \mathrm{~kg}$ of $\mathrm{Pu}$ or $5.0 \mathrm{~kg}$ of $\mathrm{PuO}_{2}{ }^{4}$. This amount will be split in half so that each food can contains a maximum of $2.25 \mathrm{~kg} \mathrm{Pu}$ or $2.5 \mathrm{~kg}$ of $\mathrm{PuO}_{2}$. No water is specified in the package containing $\mathrm{Pu}$ metal but the specifications ${ }^{4}$ allow a maximum of $1.5 \%$ water ( $75 \mathrm{~g}$ total for two food cans) in the $\mathrm{PuO}_{2}$ package. The corrosion analysis assumes that $\mathrm{Pu}$ metal compositions will be within the range displayed in Table $1^{5}$ and will contain a minimum of $98 \% \mathrm{Pu}$ with impurity levels less than or equal to $2 \%$. The impurities are assumed to be homogeneous throughout the metal, except for the lighter metals that may be concentrated near the top of the metal due to their density. Table 2, compiled from Reference 5, shows that the composition of some of the RFETS Pu metal will be outside the acceptable composition limit. The $\mathrm{PuO}_{2}$ material from RFETS is assumed to be calcined, tested to an acceptable loss on ignition value, and free of any volatile materials. Thus, 
all impurities are also oxides. Table 3, also compiled from Reference 5, shows maximum and average impurity levels in RFETS $\mathrm{PuO}_{2}$ material. Volatile materials such as chlorides, fluorides, sulfates and nitrates can produce significant corrosion of carbon steel in the presence of water. ${ }^{6}$

The maximum estimated temperatures in the $\mathrm{Pu}$ containing food cans will be uniform at $400^{\circ} \mathrm{F}$ $\left(204^{\circ} \mathrm{C}\right)$ while the $\mathrm{PuO}_{2}$ containing food cans will be $800^{\circ} \mathrm{F}\left(427^{\circ} \mathrm{C}\right)$ at the can wall and $950^{\circ} \mathrm{F}$ $\left(510^{\circ} \mathrm{C}\right)$ in the middle of the oxide pile. ${ }^{7}$

Upon arrival at SRS, the 9975 packaging assemblies will be stored in Building 105-K process room, crane maintenance area, stack area, and the crane wash area. The building environment will essentially mimic outdoor weather patterns except that the assemblies will be shielded from wind, rain, and storms. Building temperatures will range from $0^{\circ} \mathrm{F}$ to $130^{\circ} \mathrm{F}\left(-18^{\circ} \mathrm{C}\right.$ to $\left.54^{\circ} \mathrm{C}\right)$ with relative humidity levels up to $100 \% .^{8}$ The high temperature of $130^{\circ} \mathrm{C}$ is based on the loss of ventilation. The building will be heated but not cooled.

\subsection{INTERNAL CORROSION ANALYSIS OF Pu SHIPMENT AND STORAGE}

\subsection{Corrosion of the Food Can}

If the coatings on the interior of the carbon steel food can are assumed to be ineffective in preventing corrosion, corrosion could occur with sufficient moisture. However, the only water available in the can with $\mathrm{Pu}$ metal is from the can atmosphere. This atmosphere is supposed to be dry. Pu oxidation is expected to consume any available moisture prior to Fe oxidation of the carbon steel can due to a higher free energy of formation. Thus, the carbon steel can should not show any corrosion degradation.

\subsection{Plutonium Reaction with Food Can Atmosphere}

Plutonium metal is assumed to be placed in the food can in a relatively dry condition. The atmosphere in the can is determined by the quality of the air in the loading glovebox. Due to the location of RFETS, the atmosphere is expected to be relatively dry as compared with that of SRS. However, the exact partial pressure of $\mathrm{H}_{2} \mathrm{O}$ in the air is unknown and will have to be estimated based on literature values. The literature on plutonium corrosion in moist air and other oxygen containing atmospheres is reviewed by Waber ${ }^{9}$ and by Colmenares. ${ }^{10}$ These two studies are in general agreement although individual studies cover narrow temperature ranges. However, no correlation/interpretation was performed on the various observations. Also, the corrosion rate dependence on moisture levels was not defined. Continuing on this past work, Haschke ${ }^{11-13}$ evaluated unalloyed $\mathrm{Pu}$ metal in well-defined environments and developed Arrhenius data ${ }^{12}$ for reactions with water and oxygen in the high temperature region and with dry air in the low temperature region Figures 3 and 4. The anomaly that occurs with the drop in corrosion rate above $110^{\circ} \mathrm{C}$ (Figure 4) is due to the change in activation energy that is either positive or negative depending on the amount of water. The authors ${ }^{12}$ state that this is due to a mechanisitic change in the kinetics of adsorbed $\mathrm{H}_{2} \mathrm{O}$. The high temperature Arrhenius data for both oxidants was normalized to 160 Torr, the partial pressure of oxygen in air. At temperatures at $200^{\circ} \mathrm{C}$ and above, the data is independent of moisture effects. This data is represented by the following formula (1): 


$$
\begin{aligned}
\ln R\left(\mathrm{mg} / \mathrm{cm}^{2} \mathrm{~min}\right) & =13.68-(9010 \pm 280) / \mathrm{T} \\
\text { Where: } \mathrm{R} & =\text { Corrosion rate, } \mathrm{mg} / \mathrm{cm}^{2} \min \\
\mathrm{T} & =\text { Temperature, } \mathrm{K}
\end{aligned}
$$

Using formula 1 at $204^{\circ} \mathrm{C}$, the predicted Pu corrosion rate ranges from $2.58 \times 10^{-3}$ to $8.42 \times 10^{-3}$ $\mathrm{mg} \mathrm{cm} \mathrm{min}^{-1}$ or a total of $1.63 \times 10^{4}$ to $5.31 \times 10^{4} \mathrm{mg} \mathrm{cm}^{-2}$ for the 12 year shipping and storage period. This converts to $2.73 \times 10^{3}$ to $8.91 \times 10^{3} \mathrm{~g}$ (surface area $=167.7 \mathrm{~cm}^{2}$ ) 14 that exceeds the maximum weight of the $\mathrm{Pu}$ in the food can. These corrosion rates are also based on using unalloyed Pu. Additional testing was performed by Stakebake and Saba ${ }^{15}$ on Pu-1 wt.\%Ga alloy. This composition is similar to the RFETS Pu in Table 2. Their corrosion rate at $200^{\circ} \mathrm{C}$ and a water vapor pressure of 15 Torr was $4.0 \times 10^{-4}$ to $2.9 \times 10^{-2} \mathrm{mg} \mathrm{cm}^{-2} \mathrm{~min}^{-1}$. These two rates describe two different stages in the oxide growth. Stage I represents the growth of a protective oxide with the faster corrosion rate and Stage II, the period where porous oxide forms on top of the Stage I dense oxide layer. For a 12-year period, this converts to $2.52 \times 10^{3}$ to $1.83 \times 10^{5} \mathrm{mg}$ $\mathrm{cm}^{-2}$. These rates are significantly higher but are probably the result of the difference in pressures, 160 Torr for the Haschke data and water vapor equal to 15 Torr for the Stakebake and Saba data. Since the Arrhenius data is based on thin film analysis of Pu samples after relatively short time exposure (less than 300 minutes), it does not adequately represent Pu after a 12-year exposure. Thus, some oxide will be formed but the amount of oxide conversion could not be predicted by these calculations due to the complexity of the oxide formation after long time periods. The significance of this is that if there were any moisture in the can, $\mathrm{Pu}$ will oxidize before corrosion of the carbon steel can occur based on the free energy of formation for $\mathrm{PuO}_{2}$ equal to $-524 \mathrm{kJoules} / \mathrm{mole}$, and for $\mathrm{Fe}_{2} \mathrm{O} 3,-31 \mathrm{kJoules} / \mathrm{mole}$.

\subsection{Discussion of Potential Degradation Mechanisms}

\subsubsection{Food Can Embrittlement by Gallium (GA)}

GA can cause failure of iron bearing materials by three potential mechanisms: (1) liquid metal embrittlement, (2) corrosion by $\mathrm{Ga}$, and (3) by alloying with $\mathrm{Ga}$. Butt ${ }^{16}$ recently reviewed the potential of $\mathrm{Ga}$ diffusion into the 316 Stainless Steel (SS) 3013 system ${ }^{17}$ containers. The 3013 high level waste containers could see maximum temperatures greater than $200^{\circ} \mathrm{C}$ near the centerline with wall temperatures of approximately $100^{\circ} \mathrm{C}$ for up to a 50-year storage period. Gallium is known as a strong embrittling element due to liquid metal embrittlement and was demonstrated in laboratory testing with 4340 steel, iron, and the alloy Fe-3Si. ${ }^{18}$ Butt suggests that if the $\mathrm{H}_{2} \mathrm{O}$ content is kept low, thereby limiting $\mathrm{H}_{2}$ formation, the potential for $\mathrm{Ga}$ transport by gaseous diffusion would be negligible. Butt also showed that it is thermodynamically possible for $\mathrm{Ga}$ oxide to be reduced by $\mathrm{Pu}$ oxide to $\mathrm{Ga}$ at temperatures less than $527^{\circ} \mathrm{C}$. But, the $\mathrm{Pu}$ temperature for this shipment will be a maximum of $204^{\circ} \mathrm{C}$. There is very little information on past incidents of food can failure due to $\mathrm{Ga}$ embrittlement and the above mentioned data may not represent the actual atmosphere in the food can. A recent study by Williamson ${ }^{19}$, reported in Reference 17, showed that low melting temperature eutectics of Pu metal and $\mathrm{Pu}-\mathrm{Ga}$ alloys in stainless steel containers will not result in liquid formation or release plutonium by diffusion from long term storage (greater than 10 years) at $250^{\circ} \mathrm{C}$. Diffusion processes require the 
diffusion couple to have very intimate contact. The formation of an oxide on the Pu surface is likely to prevent any such contact.

\subsubsection{Plutonium/Iron Diffusion}

Iron diffusion into the plutonium can potentially weaken the carbon steel food can by creating point defects in the BCC crystal structure. ${ }^{20}$ Basic diffusion on one metallic element into another and its temperature dependence can be described by an Arrhenius equation (2):

$$
\mathrm{D}=\mathrm{D}_{0} \mathrm{e}^{-\mathrm{Q} / \mathrm{RT}}
$$

The diffusion coefficient (D) is dependent on the experimentally determined diffusion constant $\left(D_{0}\right)$ at temperature $(T$ in $K)$ with an activation energy $(\mathrm{Q})$ and gas constant $(R)$. Using this Arrhenius model to fit laboratory results, Haschke et al. ${ }^{20}$ conclude that in delta phase $\mathrm{Pu}$, no significant reaction occurs between $\mathrm{Fe}$ and $\mathrm{Pu}$ at temperatures of $140-150^{\circ} \mathrm{C}$ for up to 50 years. Delta phase $\mathrm{Pu}$ will not melt until $410-428^{\circ} \mathrm{C}$, the eutectic temperature of the $\mathrm{Pu}-10$ atomic percent Fe alloy. ${ }^{21}$ Metallic corrosion processes are enhanced by the presence of a liquid phase. An example of this was described by Seidel et al. ${ }^{22}$ in laboratory tests of metallic fuel (U-Pu-Zr alloy with up to $19 \% \mathrm{Pu}$ ) at temperatures above $700^{\circ} \mathrm{C}$, the liquid eutectic temperature in irradiated fuel. The thickness of the cladding was reduced by only $26 \%$ after one hour at $800^{\circ} \mathrm{C}$. The cladding was expected to be reduced further but the $\mathrm{Zr}$ layer on the alloy's surface retarded interdiffusion between the fuel and the cladding. It is probable that Fe diffusion into Pu will be limited (based on the $50-60^{\circ} \mathrm{C}$ difference) during the 12 year shipping and storage time for the RFETS material. However, the long term effect of $\mathrm{Fe}$ diffusion into $\mathrm{Pu}$ at $200^{\circ} \mathrm{C}$ needs further research. Haschke et al. ${ }^{20}$ further conclude that impurity diffusion, such as $\mathrm{Pu}$, into 316 stainless steel would not be a concern until temperatures are above $1000^{\circ} \mathrm{C}$. Williamson ${ }^{19}$ and an SRS study by Louthan ${ }^{23}$ do not specifically eliminate the possibility of thinning of a stainless steel can due to iron diffusion into plutonium when a $250^{\circ} \mathrm{C}$ temperature exists for 10 years or more. However, as mentioned above, diffusion requires very intimate contact and will likely be inhibited by the oxides on the Pu metal surface.

Radiation enhanced diffusion of impurities within uranium can be a problem at temperatures approaching $1000^{\circ} \mathrm{C}^{20}$ The diffusion coefficent for $\mathrm{Fe}$ in $\mathrm{Pu}$ is expected to be similar to that of uranium. Since the maximum food can temperature with $\mathrm{Pu}$ is $204^{\circ} \mathrm{C}$, radiation enhanced diffusion should not a problem for shipping and storage. On a practical side, no failures have identified in stainless steel containers with Pu metal inside due to Fe diffusion.

\subsection{INTERNAL CORROSION ANALYSIS OF $\mathrm{PuO}_{2}$ SHIPMENT AND STORAGE}

Previous documentation ${ }^{6,24}$ reviewed various corrosion reactions and corrosion rates that might occur between the RFETS SS\&C (sand, slag, and crucible) materials and water in the carbon steel cans and stainless steel vessels of the 9975 packaging assembly. Some of this material included $\mathrm{PuO}_{2}$. The corrosion interaction between the carbon steel can and water was based on the availability of up to $37.5 \mathrm{~g}$. of free water (i.e. water sitting in the can). Any water used in that report was assumed to be available for reaction as a liquid. In reality, the literature indicates that 
any water in $\mathrm{PuO}_{2}$ packaging will be in the form of a molecular layer adsorbed on the surface of the oxide. However, at a temperature greater than $100^{\circ} \mathrm{C}$, the water will be vaporized. This brings up the possibility of dew point corrosion with this amount of water in the can could occur. With vaporized water in the food can, condensation may occur on a low temperature surface, the ID surface of the food can. This is not possible if the whole can is at the steady state temperature of $427^{\circ} \mathrm{C}$ to $510^{\circ} \mathrm{C}$, as mentioned earlier. It was also assumed that the coating (organic or tin) on the carbon steel cans did not provide any corrosion protection. On the other hand, if the water is assumed to be free as a vapor and in contact with the carbon steel food can, corrosion may proceed per the following equation (2):

$$
2 \mathrm{Fe}+\mathrm{H}_{2} \mathrm{O}+\mathrm{O}_{2} \rightarrow \mathrm{Fe}_{2} \mathrm{O}_{3}+\mathrm{H}_{2}
$$

Considering that up to $37.5 \mathrm{~g}$. of water may be available per can, one mole of water is required for two moles of iron (a 1:2 ratio). Using an atomic weight of 18 for one mole of water and 37.5 g. of available water, the resulting ratio is 2.08 . This results in only 2.08 moles of available water per can. This also results in only 4.16 moles of Fe (atomic weight 56) available for corrosion. This amounts to $233 \mathrm{~g}$. of $\mathrm{Fe}$ that can corrode or oxidize to $\mathrm{Fe}_{2} \mathrm{O}_{3}$. Thus, the corrected Formula 2 for the corrosion of $\mathrm{Fe}$ is:

$$
4.16 \mathrm{Fe}+2.08 \mathrm{H}_{2} \mathrm{O}+2.08 \mathrm{O}_{2} \longrightarrow 2.08 \mathrm{Fe}_{2} \mathrm{O}_{3}+2.08 \mathrm{H}_{2}
$$

Note that the amount of $\mathrm{O}_{2}$ is not limited because the food cans are not leak tight. The dimensions of the 9975 shipping assembly are shown in Figure 2. Since the amount of corroded $\mathrm{Fe}$ is determined by the above corrosion calculations, the time it takes to consume the steel food can (Can $A$ in Figure 2) also be calculated by using the can dimensions ${ }^{2}$ and the standard corrosion calculation based on corrosion coupons. ${ }^{25}$ The dimensions for Can A result in an inner surface area of $96.9 \mathrm{in}^{2}$. See Reference 25 for typical area calculations. The corrosion. calculation (4) is as follows:

$$
\text { Corrosion Rate }(\text { mils } / \text { year })=\frac{\text { Weight loss } \left.(\mathrm{g} .) \times \mathrm{K} \text { (constant }=3.45 \times 10^{6}\right)}{\text { Area }\left(\mathrm{cm}^{2}\right) \times \text { Time (hours) } \times \text { Density }\left(\mathrm{g} / \mathrm{cm}^{3}\right)}
$$

This equation is normally used to measure corrosion on the full surface area of the corrosion coupon, which in this case is the inner surface of the can. The constant $\mathrm{K}$ is used for unit conversion. This is a very conservative calculation for corrosion of the carbon steel can since it assumes that the entire ID surface will be corroded. The weight of the inner can A is $186 \mathrm{~g}$. and the outer can B is $230 \mathrm{~g}$..

Assuming that the water in the can will be of high purity and neutral $\mathrm{pH}$ with a corrosion rate of $50 \mu \mathrm{m}$ ( 2 mils) per year or less, ${ }^{26}$ the time to achieve the predicted weight loss can be calculated per Equation 5.

$$
\text { Time (hours) }=\frac{\text { Weight loss }(\mathrm{g} .) \times \mathrm{K}\left(\text { constant }=3.45 \times 10^{6}\right)}{\text { Corrosion Rate }(\text { mils } / \text { year }) \times \text { Area }\left(\mathrm{cm}^{2}\right) \times \text { Density }\left(\mathrm{g} . / \mathrm{cm}^{3}\right)}
$$


The time value of 9.1 years was calculated and presented in Table 4 as the number of years to consume the molar value of $\mathrm{Fe}(233 \mathrm{~g}$.) and also as a \% of the 12-year shipping and storage period. Can A (186 g.) will be consumed with sufficient moisture remaining to partly corrode Can B.

$$
\text { Corrosion (g.) of Can B } \div 230 \text { (in \%) }=(233 \text { g. }-186 \text { g. }) / 230=47 \text { g. } \div 230=20 \%
$$

With this amount of corrosion, a safe conclusion is that Can B may be penetrated. The 304L SS PCV will not be impacted since the available water is used in the oxidation of the steel cans.

If the composition of the stored $\mathrm{PuO}_{2}$ is within the range of Table 1 , calcined to an acceptable loss on ignition value, and no volatile materials (fluorides, chlorides, nitrates and sulfates) corrosion of the carbon steel can is not anticipated. Even if the carbon steel cans are penetrated. using the assumption of free water, the integrity of the PCV is not at risk.

\subsection{CONCLUSION}

Corrosion calculations were performed using $\mathrm{Pu}$ metal exposed to relatively dry atmospheres. Although the calculations could not predict the long-term performance, some conversion to oxide is expected. Since no water is expected in the Pu filled package, corrosion of the carbon steel cans and stainless steel vessels is not expected. Potential diffusion mechanisms were discussed, but oxide formation on $\mathrm{Pu}$ should prevent intimate contact and subsequent diffusion during the 12-year period. Corrosion in the oxide filled packages is conservatively expected, but will not impact the integrity of the PCV. On an overall basis, internal corrosion of the Model 9975 shipping package with $\mathrm{Pu}$ or $\mathrm{PuO}_{2}$ is not expected during the 12-year shipping and storage period. This conclusion is based on $\mathrm{Pu}$ contents greater than or equal to $98 \%$ and calcined $\mathrm{PuO}_{2}$. If any metal shipments have less than $98 \% \mathrm{Pu}$, they can be reviewed on a case by case basis.

\subsection{REFERENCES}

1) United States Department Of Energy, Savannah River Site Drawing Number R-R2-F0006 Revision 2, “9972-9975 Series Packagings - Drum Assemblies (U),” July 7, 1997.

2) W. M. Massey to P.R. Vormelker, Can Dimensions, e-mail, September 23, 1998.

3) P. R Vormelker, WSRC-TR-98-00454, "External Corrosion Analysis of Model 9975 Packaging Container (U), January, 1999.

4) T. D. Woodsmall, SFS-RPS-98-0116, Rev. 0, KAMS Safety Analysis for Container Qualification Inputs and Assumptions (U), September 15, 1998, p. 3.

5) A. M. Murray, SRT-CHT-98-0145, Preliminary Assessment of RFETS Plutonium Metal and Oxide for Storage in the SRS KAMS Facility, December 7, 1998.

6) P. R. Vormelker, SRT-MTS-98-4109, Compatibility Issues for SS\&C \& Fluoride Residues in 9975 Packaging Assemblies, September 9, 1998. 
7) Steve Hensel, SRS Calculation: M-CLC-K-00633, Steady-State Thermal Analysis of Plutonium Storage in $K$-Area, January 1999.

8) B. K. Tharakan, WSMS Calculation: S-CLC-K-00145 Rev. A, Fire Accident Analysis Report, October 28, 1998.

9) J. T. Waber, Corrosion and Oxidation, Chapter 6 in Plutonium Handbook, Vol. 1, O. J. Wick, Editor, American Nuclear Society, Illinois (1980) pp. 147-189.

10) C. A. Colmenares, Prog. Solid State Chem., 9 (1975) 139.

11) J. M. Haschke, Reactions of Plutonium and Uranium with Water: Kinetics \& Potential Hazards, LA-13069, Los Alamos National Laboratory, December 1995, p. 21.

12) J. M. Haschke, et al, Reaction Kinetics of Plutonium with Oxygen, Water and Humid Air: Moisture Enhancement of the Corrosion Rate, J. Alloys and Compounds, 243(1996) pp. 23-35.

13) J. M. Haschke and J. C. Martz, Plutonium Storage, Encyclopedia of Environmental Analysis and Remediation, Volume 6, R. A. Meyers, Editor, New York, (1998), pp. 2335.

14) L. W. Gray, DP-1484, The Kinetics of the Ambient Temperature Dissolution of Pu Metal in Sulfamic Acid, March 1978.

15) J. L. Stakebake and M. A. Saba, Reaction Kinetics for the High Temperature Oxidation of Pu-1wt.\%Ga in Water Vapor, J. Less-Common Met., 158 (1990) pp. 221-237.

16) D. P. Butt, et al, Ga Issues in 3013 Containers: Comments from D. P. Butt, D. G. Kolman, and M. Stan, LA-UR-2866, Los Alamos National Laboratory, February 6, 1998.

17) DOE Standard, DOE-STD-3XXX-99 Draft, Revision G, Stabilization, Packaging, and Storage of Plutonium-Bearing Materials, U.S. Department of Energy, January 15, 1999.

18) M. H. Kamdar, Liquid-Metal Embrittlement, ASM Metals Handbook, Vol. 11, Failure Analysis and Prevention, ASM International, Metals Park, OH (1986) pp.235-238.

19) M. A. Williamson, LA-UR-99-136, Phase Equilibria Issues, Los Alamos National Laboratory, January 1999.

20) J. M. Haschke, K. Veirs and C. Hoth, NMT-5: 98-002, Summary of Technical Assessments on Pu-Fe Compatibility, Los Alamos National Laboratory, October 2, 1997.

21) ASM Handbook Vol. 3, H. Baker Editor, Alloy Phase Diagrams, ASM International, Metals Park, OH (1997) p. 200. 
22) B. R. Seidel et al., A Decade of Advance in Metallic Fuel, CONF-9011-1-76, 1990 Winter Meeting, American Nuclear Society, November 1990.

23) M. R. Louthan, Jr., SRT-MTS-98-2020, Storage Criteria and Plutonium Metal Interactions with Container Materials, No date provided.

24) P. R. Vormelker, SRT-MTS-98-4132, Water Limiting Corrosion Reactions for RFETS SS\&C Materials in 9975 Packaging Assemblies (U), September 30, 1998.

25) ASTM Standard G 1-90, Standard Practice for Preparing, Cleaning, and Evaluating Corrosion Test Specimens, American Society for Testing and Materials, 1994.

26) Corrosion Data Survey, Metals Section, Fifth Edition, N. E. Hammer, Editor, National Association of Corrosion Engineers, Houston, TX (1974), p. 252.

\section{ACKNOWLEDGEMENTS}

The author appreciates the timely assistance from Susan Issacs of 773-A Library Services. 
Table 1. Plutonium Metal Feed Specifications for the Weapons Program

\begin{tabular}{|c|c|c|}
\hline Impurity & 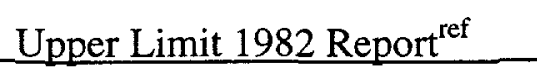 & Upper Limit 1985 Report $^{\text {ref }}$ \\
\hline Aluminum + & $10 \times(\mathrm{Al} \mathrm{ppm})+10 \times(\mathrm{Si} \mathrm{ppm})$ & $10 \times(\mathrm{Al} \mathrm{ppm})+10 \times \mathrm{Si} p \mathrm{pm})$ \\
\hline Silicon + Galium ${ }^{1}$ & $+4 \times(\mathrm{Ga} \mathrm{ppm}) \leq 1300 \mathrm{ppm}$ & $+4 \times(\mathrm{Ga} \mathrm{ppm}) \leq 1300 \mathrm{ppm}$ \\
\hline Americium & $200 \mathrm{ppm}$ & $200 \mathrm{ppm}$ \\
\hline Beryllium & $1 \mathrm{ppm}$ & $3 \mathrm{ppm}$ \\
\hline Boron & $5 \mathrm{ppm}$ & $50 \mathrm{ppm}$ \\
\hline Cadmium & $10 \mathrm{ppm}$ & $10 \mathrm{ppm}$ \\
\hline Calcium & $500 \mathrm{ppm}$ & $500 \mathrm{ppm}$ \\
\hline Carbon & 200 ppm & $200 \mathrm{ppm}$ \\
\hline Chromium & $100 \mathrm{ppm}$ & $100 \mathrm{ppm}$ \\
\hline Copper & $100 \mathrm{ppm}$ & $100 \mathrm{ppm}$ \\
\hline Iron + Nickel & $\mathrm{Fe} \mathrm{ppm}+\mathrm{Ni} \mathrm{ppm}<400 \mathrm{ppm}$ & $\mathrm{Fe}$ ppm $+\mathrm{Ni}$ ppm $<400$ ppm \\
\hline Lead & $100 \mathrm{ppm}$ & $100 \mathrm{ppm}$ \\
\hline Lithium & $10 \mathrm{ppm}$ & - \\
\hline Magnesium & $500 \mathrm{ppm}$ & $500 \mathrm{ppm}$ \\
\hline Manganese & $100 \mathrm{ppm}$ & $100 \mathrm{ppm}$ \\
\hline Neptunium & $50 \mathrm{ppm}$ & $100 \mathrm{ppm}$ \\
\hline Phosphorus & $100 \mathrm{ppm}$ & - \\
\hline Tantalum & $100 \mathrm{ppm}$ & $100 \mathrm{ppm}$ \\
\hline Thorium & $50 \mathrm{ppm}$ & $100 \mathrm{ppm}$ \\
\hline Tin & $100 \mathrm{ppm}$ & $100 \mathrm{ppm}$ \\
\hline Titanium & 100 ppm & $100 \mathrm{ppm}$ \\
\hline Tungsten & - & 200 ppm \\
\hline Uranium & $100 \mathrm{ppm}$ & $100 \mathrm{ppm}$ \\
\hline Zinc & - & $100 \mathrm{ppm}$ \\
\hline Zirconium & 100 ppm & - \\
\hline
\end{tabular}


TABLE 2. Maximum and Average Impurity Levels Found in Pu Metal During Elemental Analysis of Specific Group A and B metals (compiled from Reference 6) Values are in ppm.

\begin{tabular}{|c|c|c|c|c|c|c|c|c|c|c|c|c|c|c|c|c|c|}
\hline Element & $\mathrm{Am}$ & A & $\mathrm{Be}$ & $\mathrm{C}$ & ${ }_{1} \mathrm{Ca}$ & $\mathrm{Cr}$ & $\mathrm{Cu}$ & $\mathrm{Fe}$ & $\mathrm{Ga}$ & $\mathrm{K}$ & $\mathrm{Mg}$ & $\mathrm{Mn}$ & $\mathrm{Ni}$ & $\mathrm{Pb}$ & $\mathrm{Si}$ & ${ }_{\mathrm{Sn}}$ & $\mathrm{Ta}$ \\
\hline Group & & & & & & & & & & & & & & & & & \\
\hline$\overline{A(C R)}$ & - & 61 & 0.22 & 122 & 500 & 136 & 12 & 518 & 120 & 120 & 1000 & 44 & 116 & 29 & 90 & 6 & - \\
\hline Average & - & 46 & 0.07 & - & 107 & 38 & 7 & 388 & 58 & 5 & 305 & 4 & 70 & 9 & 9 & 5 & - \\
\hline$A(E R)$ & 91 & 21 & $<.38$ & 53 & 18 & 42 & 8 & 196 & - & - & - & - & 11 & 17 & 42 & - & 30 \\
\hline Average & 77 & 23 & 0.10 & 37 & - & 18 & 16 & 36 & 349 & - & - & - & 11 & 13 & 33 & - & 31 \\
\hline $\mathrm{B}(\mathrm{ER})$ & 191 & 73 & $0.58 \mid$ & 479 & - & 182 & 400 & 180 & $1.12 \%$ & - & - & - & 1088 & 76 & 1295 & - & 150 \\
\hline Avg. & 177 & 52 & 0.40 & 188 & - & 105 & 94 & 769 & 9611 & - & - & 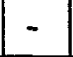 & 289 & 45 & 89 & & 88 \\
\hline
\end{tabular}

Notes: CR - Calcium Reduction Process ER - Electrorefining Process

TABLE 3. Maximum and Average Impurity Levels Found in $\mathrm{PuO}_{2}$ During Elemental Analysis of Selected Batches (compiled from Reference 6) - Values are in ppm.

\begin{tabular}{|c|c|c|c|c|c|c|c|c|c|c|c|c|c|c|c|c|c|c|c|}
\hline Element & $\mathrm{Al}$ & & $\mathrm{Be}$ & $\mathrm{Ca}$ & $\mathrm{Cd}$ & $\mathrm{Cr}$ & $\mathrm{Cu}$ & $\mathrm{Fe}_{\text {, }}$ & $\mathrm{Ga}$ & $\mathrm{K}$ & $\mathrm{Mg}$ & $\mathrm{Mn}$ & Mo & $\mathrm{Ni}$ & $\mathrm{P}$ & $\mathrm{Pb}$ & $\mathrm{Si}$ & Sn & $\mathrm{V}$ \\
\hline Group & & & & & & & & & & & & & & & & & & & \\
\hline $\mathrm{PuO}_{2}$ & 26 & 3 & 2.00 & 220 & 39 & 46 & 10 & 478 & 71 & 50 & 15 & 12 & 10 & 37 & 500 & 50 & 45 & 20 & 5 \\
\hline $\begin{array}{l}\mathrm{PuO}_{2} \\
\text { Avera }\end{array}$ & 17 & - & 0.79 & 106 & - & 34 & 6 & 388 & 41 & 20 & 4 & 10 & - & 27 & - & 27 & 19 & 14 & - \\
\hline
\end{tabular}

TABLE 4. Fe Corrosion vs. Available Water

\begin{tabular}{|c|c|c|c|c|c|c|}
\hline $\begin{array}{l}\text { Water } \\
\text { moles }\end{array}$ & $\begin{array}{l}\text { Water } \\
\text { g. }\end{array}$ & $\begin{array}{c}\mathrm{Fe} \\
\text { moles }\end{array}$ & $\begin{array}{l}\mathrm{Fe} \\
\mathrm{g} .\end{array}$ & $\begin{array}{c}\text { Corrosion Rate } \\
\mu \mathrm{m} / \mathrm{yr} \\
\end{array}$ & $\begin{array}{r}\text { Time } \\
\text { yr's } \\
\end{array}$ & $\begin{array}{l}\text { Time, \% } \\
\text { of } 12 \mathrm{yr} \text { 's }\end{array}$ \\
\hline 2.08 & 37.5 & 4.16 & 233 & 50 & 9.1 & 75 \\
\hline
\end{tabular}

Note: The corrosion rate for Fe in high purity water is assumed to be $50 \mu \mathrm{m}$ per year. 


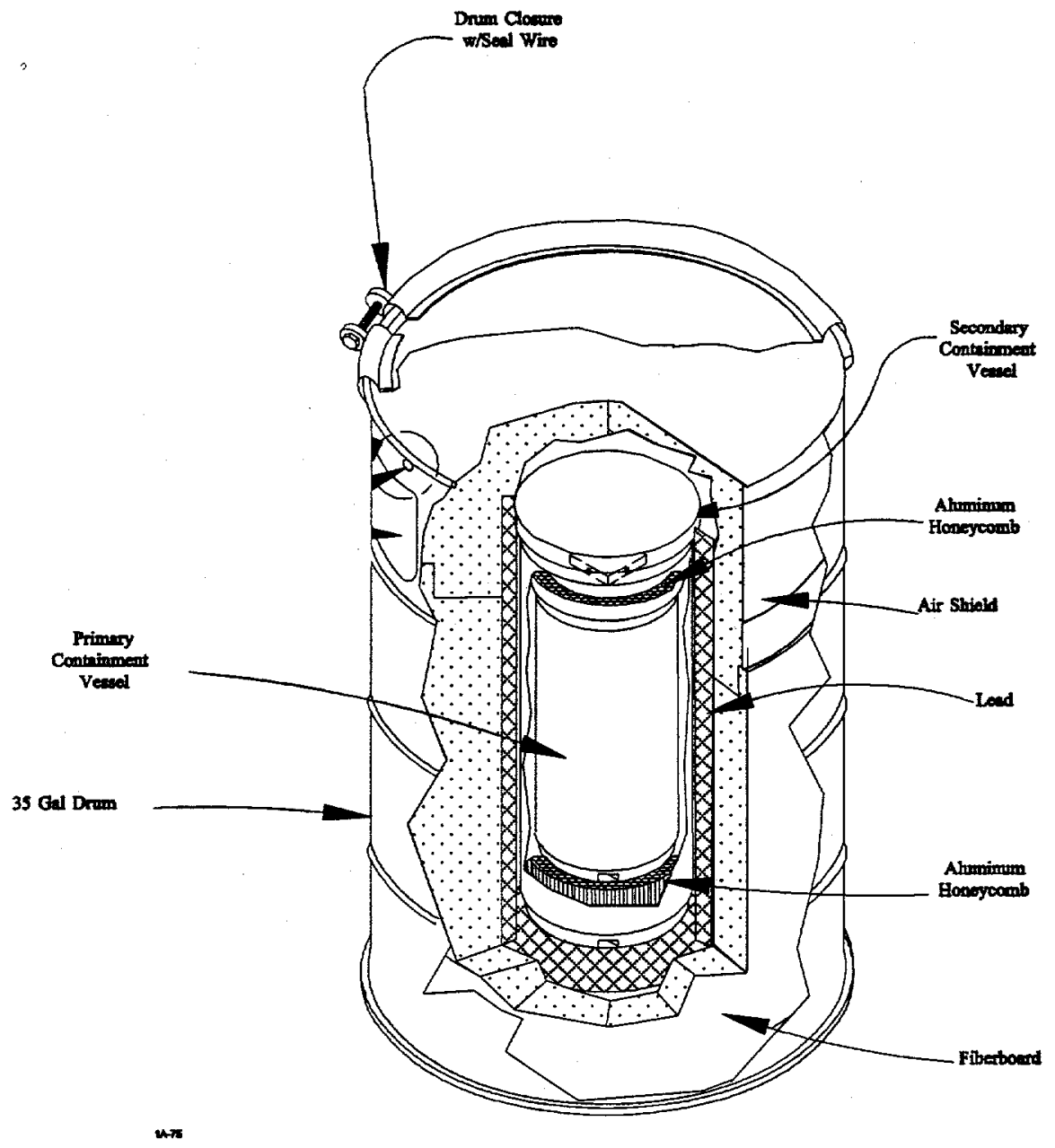

Figure 1. Overall Schematic of the Model 9975 Packaging Assembly. ${ }^{1}$ 


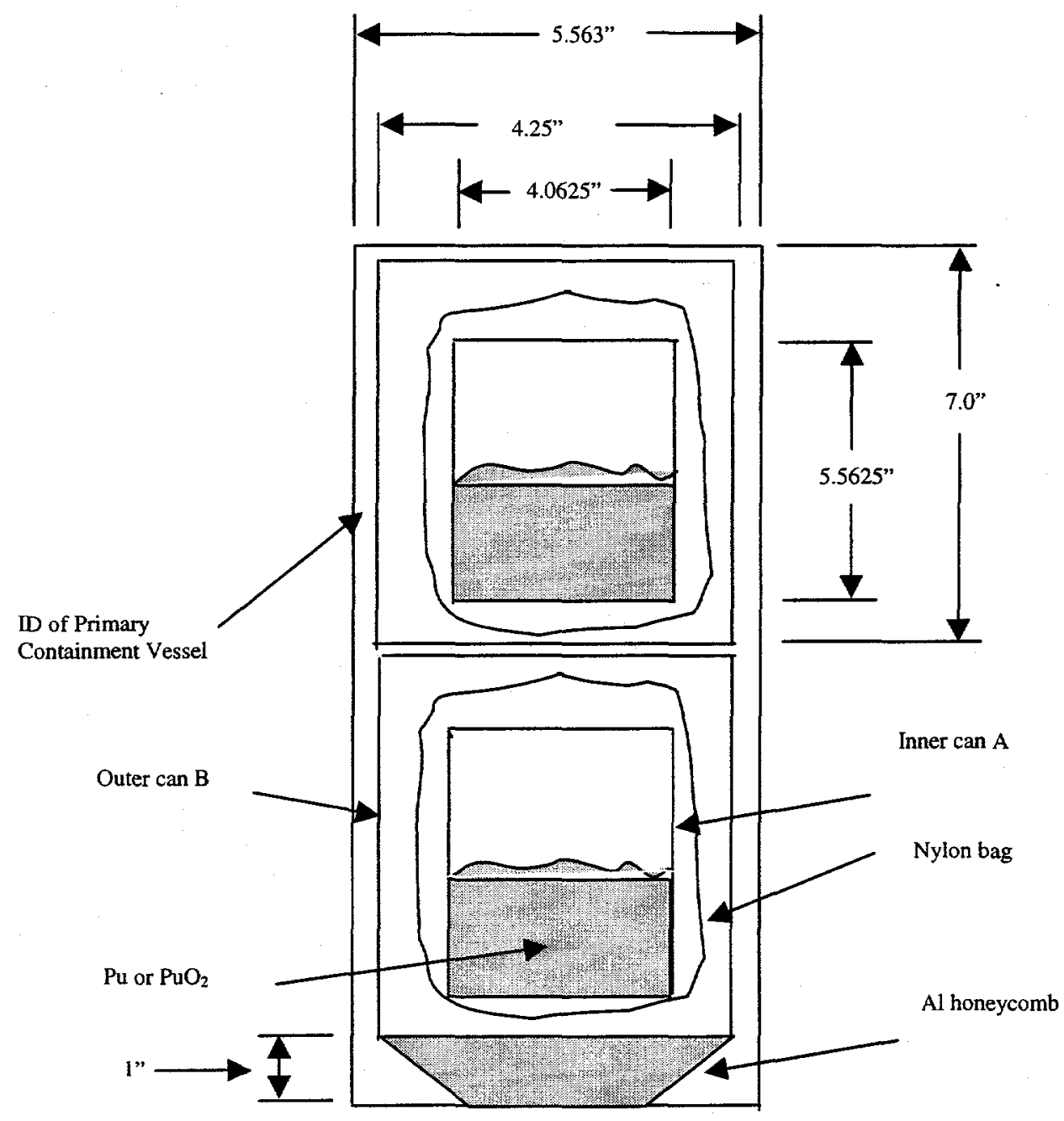

Figure 2. Author's conception of Model 9975 Shipping Container showing location of vessels and food cans with dimensions. ${ }^{2}$ 


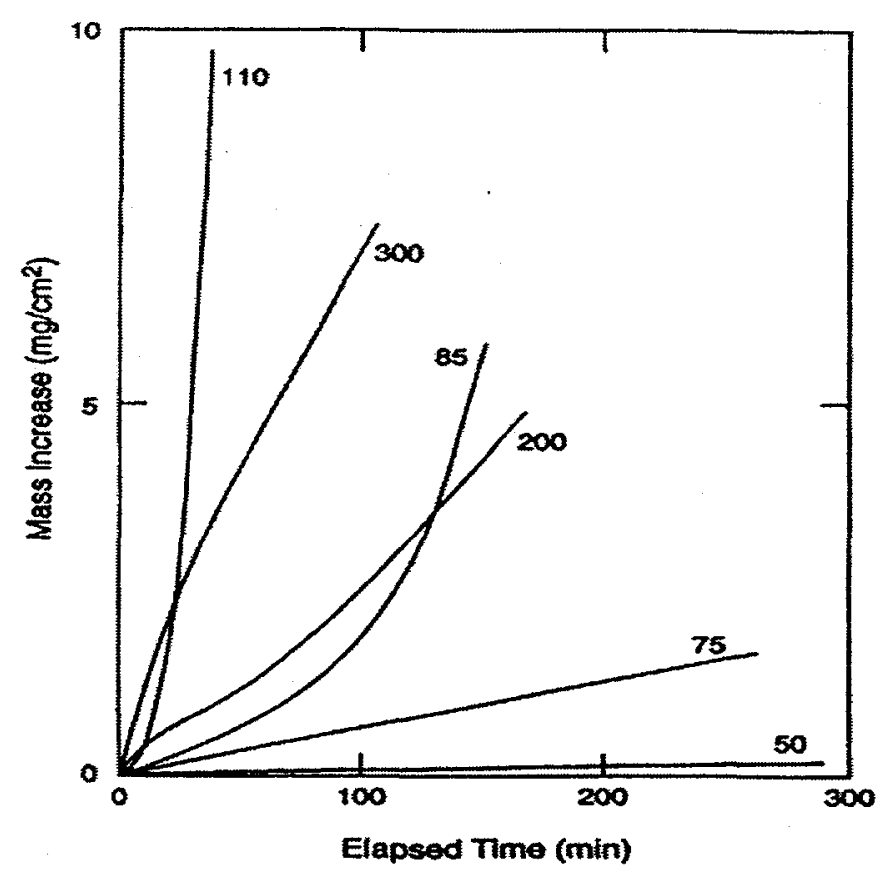

Figure 3. Time dependence of mass gain of unalloyed plutonium with water vapor at 15 Torr pressure and temperatures in the $50-300^{\circ} \mathrm{C}$ range. (From Ref. 12, p. 25) 


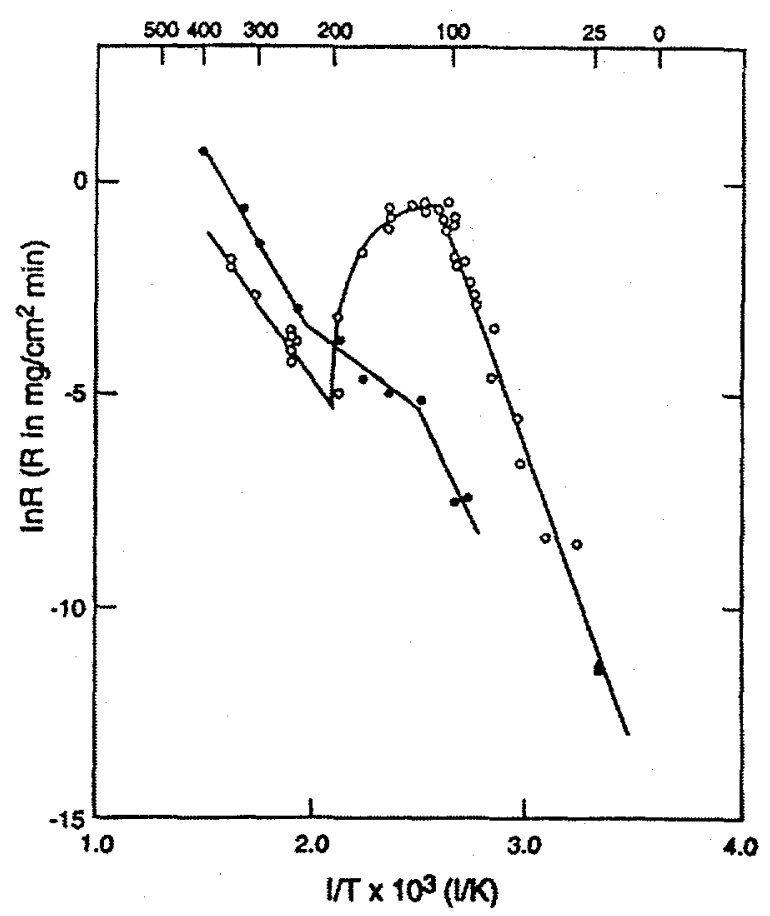

Figure 4. Arrhenius data for the reactions of unalloyed plutonium with water vapor and water-saturated air over the $25-400^{\circ} \mathrm{C}$ range. (From Ref. 12, p. 25)

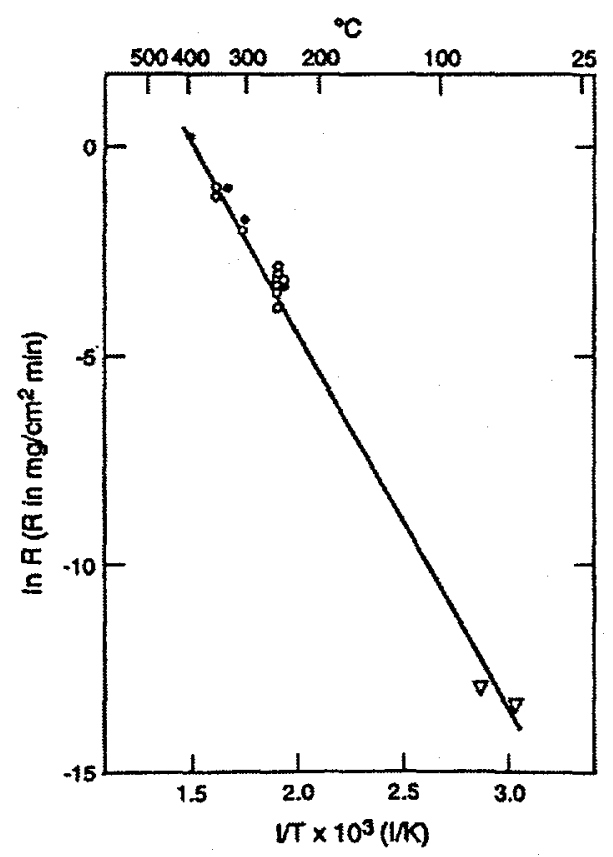

Figure 5. Combined Arrhenius data for the reactions of unalloyed plutonium with water and oxygen in the high temperature regime and with dry air in the low temperature regime. (From Ref. 12, p. 28) 


\section{WSRC INTERNAL DISTRIBUTION}

E. K. Opperman, 773-54A

R. J. Gromada, 773-53A

M. N. Van Alstine, 773-53A

M. W. Barlow, 104-K

D. H. Poss, 707-C

D. P. Eisele, 705-K

T. D. Woodsmall, 707-C

A. J. Cappucci, 707-C

C. R. Wolfe, 773-A

A. M. Murray, 773-A

T. L. Capeletti, 773-41A

N. C: Iyer, 773-A

R. L. Bickford, 730-A

R. L. Sindelar, 773-41A

T. E. Skidmore, 730-A

W. D. Daugherty, 730-A

C. F. Jenkins, 730-A

L. Hillary, 773-41A

SRTC Records, 773-52A 